\title{
AGORAPHOBIA PROBLEM OF ANNA FOX IN THE WOMAN IN THE WINDOW BY A.J. FINN
}

\author{
Gusti Ayu Made Rai Suarniti \\ Universitas Warmadewa \\ raisuarniti78@gmail.com
}

\begin{abstract}
The title of this scientific writing is Agoraphobia Problem of Anna Fox in The Woman in the Window by A.J. Finn. The aims of this research were to find out the agoraphobia problem experienced by Anna Fox found in the novel and the influences of agoraphobia toward herself and her surroundings. The data are collected by reading the novel repeatedly and using the note-taking technique to find out the statements that related to the topic. Based on the result of the analysis, it is found that Anna Fox's agoraphobia problem because of Post-Traumatic Stress Disorder (PTSD). The disease influences herself and her surroundings by ruins her body because consuming a lot of drugs, made her lose her job, made her have a bad temperament, depression, and made her insecure.
\end{abstract}

Keywords: agoraphobia; Anna Fox

\section{INTRODUCTION}

Literature is act of expressing artistic and creative work. Literature can create its own world as a product of the unlimited imagination. It is a part of human works in written forms and through language, which contains their ideas, thought, feeling, hope and experience. This purpose of creating literature then leads to the existence of literary works. Literary work contains all problem about life which happens in a society for instance: social life, tradition problem, culture, daily incident or can be author's private experiences. Human creates literary work for many purposes. One of those purposes is for knowledge because it can give particular values and messages to the readers. After reading a literary work, the readers may get a certain impression of what he/she has read. It can help us to develop mature sensibility for all things because it exercises our emotions through arousing our interest, concern, tension, sympathy, laughter, and excitement. It can relieve human, either writer or readers from the pressure of emotions.

According to Wellek and Warren literature text divided into three genres, those are Poetry, Drama and Prose. Prose fiction as a literary genre is made up of the short story, novella and novel (Wellek \& Warren, 1949: 120). A novel is an invented prose narrative that is usually long and complex and deals especially with human experience through a usually connected sequence of events. There are two important elements namely intrinsic and extrinsic elements. The intrinsic aspect provides the elements which builds up the structure of a literary work. All of the elements had functionally a relation to one another and for the extrinsic aspect it is about the things that can't really be found inside the story itself. It was not the material but the facts and information that supports and surrounds the story and indirectly influence the structure of the literary works. One of the intrinsic elements that build up the story of this fictional work is character because character representative the story, from the beginning until the end of the story. Here, character became one of the most important aspects of novel that is interesting to be analyzed because we can study various kinds of human behavior. In addition, the author must choose certain methods to present the main character in the novel because the main character had an important role in a story. To analyzed the character in the story, we can use tridimensional of the character to know their physiological, sociological and psychological 
of the character but from this explanation the writer is more focus in analyzing the psychological problem reflected in the novel which discussed about phobia. In this case, The Woman in the Window by A. J Finn is chosen to be analyzed.

\section{METHOD}

Method means a systematic, organized series of steps that ensure maximum objectivity and consistency in researching the problem. To make this scientific writing, there are three steps that would be done, they include data source, data collection, and data analysis.

The data source was taken from an English novel entitled The Woman in the Window by A. J. Finn. The writer chose this novel because in this novel the writer can found the complex psychological problem from the main character named Anna Fox (Finn, 2018).

The second method is data collection. The data were collected by applying the method of library research in order to get more authentic information. Library search itself is done by reading the novel repeatedly and intensively and finding out the statements that closely related to the topic.

The third step is analysis. Data analysis would be descriptively analyzed after classifying them based on the theory of literature and the theory of psychology. The theories of literature are proposed by Lajos Egri about three dimensions of characterization : physiology, sociology, and psychology (Egri, 1946), Kelley Griffith about four aspects of setting (Griffith, 1994: 52). William Kenney about element of fiction: plot, setting, character, point of view and theme (Kenney, 1966:7). Christopher Russel's Reaske about six devices of characterization (Reaske, 1970: 46) Robert Di Yanni about genre of character: static and dynamic character (DiYanni, 1990: 36) Abrams about the relationships between psychological criticism with a work of literature (Abrams, 1999: 247). The last is Rich ard Gill about character \& characterization (Gill, 1995). Meanwhile, the theories of psychology are proposed by Sigmund Freud about phobia as a panic disorder (Freud, 1949: 90) Karl Bernhardt about psychology as biological science (Bernhardt, 1953: 16). Kasschau about psychology as scientific study of behavior and mental processes(Kasschau, 1995: 7). Braun and Darwin about anxiety as a catalyst of phobia ((Braun \& E, 1983:511) Haber and Runyon about fear as a catalyst of phobia Haber and Runyon about fear as a catalyst of phobia (Haber \& Runyon, 1983: 334) The last, Frampton about definition of agoraphobia which is derived from Greek word ( Phobos) means fear and (agora) means a place at assembly ((Frampton, 1984: 16).

\section{DISCUSSION}

\section{Agoraphobia Problem of Anna Fox}

Anna Fox is the main character of the story. She has got psychological problem after the incident. She falls down into a cliff. She is scared and feels anxiety because of the accident. Her husband (Ed) and her daughter (Olivia) had passed away from the accident. She blames herself by the accident. She wants to help her family however she cannot do anything. She feels regret of her decision to do a vacation in Vermont area. She could not accept the reality of this tragedy. Anna is really suffering from the accident. She has got a traumatic and she feels afraid to go outside and staying in her house lonely. It can be seen in the quotation below:

"That's when your troubles started. Your problems going outside. Post-traumatic stress. Which I-I mean, I can't imagine."

God, how I cowered beneath the hospital fluorescents; how I panicked in the squad car. How I collapsed, those first times leaving the house. Once and twice more, until at last I dragged myself back inside." (Finn, 2018: 313)

The police comes to Anna house to ask her about the tragedy. Anna recalls the memory of the accident in the cliff but she feels panic after remembers about the accident. She tries to go outside her house however she falls down unconsciously. After this incident the doctor diagnosed her that she is not only suffering a Post-Traumatic Stress Disorder (PTSD) but also has got agoraphobia problem. The Analysis can be explained by the following quotation:

"At the hospital, they told me I was in shock. Then shock became fear. Fear mutated, became panic. And by the time 
Dr. Fielding arrived on the scene, I was well, he said it simplest, said it best: "A severe case of agoraphobia."

I need the familiar confines of my home because I spent two nights in that wilderness, beneath those huge skies. I need an environment I can control because I watched my family as the slowly died." (Finn, 2018: 321)

Anna feels bored in her house for several months. She tries to get rid of her boredom and she joined an Agora site in the internet. She wants to know more people who has got the same problem as her. She has got a lot of friends from the agora sites and makes a good relationship with them. She is become famous because she is a psychological doctor for children. They tell their problem with Anna and Anna tries to give them solution. From there Anna began to tell the types of agoraphobia she experiences and know that a lot of people have the same phobia as her but not all of them are afraid of the open spaces. The Analysis can be explained by the following quotation:

"Many of us - the most severely afflicted, the ones grappling with posttraumatic stress disorder-are housebound, hidden from the messy, massy world outside. Some dread the heaving crowds; others, the storm of traffic. For me, it's vast skies, the endless horizon, the sheer exposure, the crushing pressure of the outdoors. "Open spaces," the DSM-5 calls it vaguely." (Finn, 2018: 27)

On Halloween night, Anna watches her favorite black and white movie, several kids throw eggs at Anna's window. She is angry but she cannot go outside, because she is afraid to go outside. She begs the kids to stop throwing the eggs from the window however the kids still throw the eggs to her window. She becomes very angry of the attitude of the kids, she decides to go outside of her house to drives the kids away. She wants to drives away the kids but she falls down in front of her door step unconsciously. She feels panic and she has no power to against her anxiety. This can be seen in quotation below:

"I jolt the door open. Light and air blast me. I could swear I hear a crack, as of a felled tree. Then it bulges toward me, swelling, now rushing, a boulder flung from a catapult; slams me with such force, walloping my gut, that I fold. My mouth opens like a window. Wind whips into it. I'm groaning, sliding, avalanching, one hand scraped along the brick." (Finn, 2018: 53)

Anna feels angry because of the kids pelts her house with eggs. She is panic and tries to go outside of her house but she crouches at her doorstep and falls down unconsciously. Suddenly, there is a woman who helps her. The woman is her new neighbor (Katie). Anna thought that Katie is Jane Russell (Ethan's mother). Katie asked about Anna's condition. Anna tells the story about her trauma, she tells the accident in the cliff which makes her family passed away. After that she has got an anxiety and always in panic condition. According to the doctor she has a got trauma and leads to agoraphobia problem. The Analysis can be explained by the following quotation:

"So, Anna. You'll notice I'm not asking what made you this way."

"Overweight?" I say. "Prematurely gray?" I really, I'm soused.

She sips her wine. Agoraphobic."

"Well..." if we're trading confidence, then I suppose: "Trauma. Same as anyone." I fidget. "It got me depressed. Severely depressed. It isn't something I like to remember." (Finn, 2018: 93)

Anna tries to go outside from her house. However, it never success she is really in suffering because of Agoraphobia. She locks herself in her house for several weeks. She does feels better after a therapy however she still doesn't have the courage to go outside of her house lonely. She is in suffering for almost a year. The doctor tries to take her outside of her house even though it is only a few meters from her house but she always feels worry and anxiety. She is panic and decides to come back to her house. The Analysis can be explained by the following quotation:

"Nearly a year. I haven't left the house in nearly a year. Well, almost. Five times in eight weeks I've managed to venture outside, out back, into the garden. The umbrella projects straight ahead of me, like a saber, like a shield. And then I step outside." (Finn, 2018: 32) 
Anna is afraid of open space. She needs something to help her feel comfortable. She needs an umbrella to make her comfortable when going outside. She uses an umbrella from her husband in doing a therapy. The doctor allows her to use an umbrella in going outside of her house. As far as it makes her feelings comfortable. She always uses umbrella and must be accompanied by her personal doctor in going outside of her house. It can be seen in the following quotation:

"Remember, you've got your secret weapon," Dr. Fielding calls. It's not a secret, I want to cry; it's fucking umbrella, wielded, in broad daylightand unexpectedly it works: I'm conducted down the steps, and across a few yards of lawn. Until the panic wells within, a rising tide that swamps my sight, drowns out Dr. Fielding's voice. And then... best not to think of it." (Finn, 2018: 32)

Based on the above quotation, Anna is really afraid to go outside of her house lonely. She feels afraid to go outside without her personal doctor (Dr. Fielding). She also has to uses an umbrella to go outside of her house and accompanied by her doctor. The umbrella is very important to Anna because it can covering her sight to see the outsider space. She feels safe and comfortable under the umbrella and it makes her feels better.

\section{The Influences of Agoraphobia toward Herself (Anna Fox)}

It has been almost a year for Anna fox to stay in her lonely house. She feels afraid to go outside of her house and she cannot do any activities as usual. The doctor diagnosed her that she has got an agoraphobia problem. Her world changes instantly. She is in a deep depression, frustration, and feeling hopeless to face her future. Her life is gloomy and becomes dark. All of Anna's condition above can be seen as the following quotation:

"As a doctor, I say that the sufferer seeks an environment she can control. Such is the clinical take. As a sufferer (and that is the word), I say that Agoraphobia hasn't ravaged my life so much as become it." (Finn, 2018: 27)
She tries to have a friend from the internet through Agora website. She becomes famous in the Agora site because she is a psychological doctor for children. She helps many friends who have the same problems as her through the website. Anna is a great psychological doctor. However, her world becomes very dark after the tragedy in her family. She misses her world as a psychological doctor very much however she has no power to against her agoraphobia. All of Anna's condition can be seen in the following quotation:

"I swipe my phone on and take to the internet in search for my patients. My former patients. Ten months ago, I lost them all: I lost Mary, nine years old, struggling with her parents' divorce; I lost Justin, eight, whose twin brother had died of melanoma: I lost Anne Marie, at age twelve still afraid of the dark. I lost their tears and their troubles and their rage and their relief. I lost nineteenth children all told. Twenty, if you count my daughter" (Finn, 2018: 46)

Anna has got a very bad temperament because of her agoraphobia. She is always in nerve and anxiety if someone comes to her house. At that time, Anna wants to drink a glass of wine and she hears her doorbell rings. She drops her glass because she is shock and start swearing other dirty words such as "Fuck", "Shit" even by small incident. The condition of Anna in her house can be seen in the following quotation:

"Late afternoon, and I'm pouring a California pinot noir into a tumbler when the doorbell chimes. I drop my glass. It explodes, a long tongue of wine licking the white birch. "Fuck" I shout. (something I've noticed: In the absence of others, I swear more often and more loudly. Ed would be appalled. I'm appalled.)" (Finn, 2018: 37)

Anna feels embarrassed because of her Agoraphobia especially in the night of October. When three children throw her house with some eggs. She is angry and forces herself to go outside of her house but Anna suddenly panic and curls herself in front of her house. At that time, there is a woman comes to help her and carries her into her house. Anna thought that the woman is her new neighbors (Jane Russell). 
However, she is Katie and Anna does not know about her identity. They talk together along the night. Anna tells Katie about her agoraphobia and feels so sorry about the tragedy in Anna's family. Nobody understand about her condition as well as her neighbors. So, Katie is the first neighbor who cares of her. The others thought that she is a weird woman. They are afraid and never care about Anna's condition like Katie. The evidence above can be seen as the following quotation:

"Thank you for bringing me inside. I'm very embarrassed." "Oh, don't_-" "No, I am. Very. It won't become a habit, I promise."

"So, it's happened before? You going outside, and...? "Back in the spring. Delivery guy left my groceries on the front steps, and I thought I could just...grab them." "And you couldn't?" "I couldn't. But there were lots of people passing by that time. It took them a minute to decide I wasn't crazy or homeless." (Finn, 2018: 58)

Anna is opening the Agora website, she is scanning the message in her inbox and then a chat box appears on her screen. She gets a message from Sally in the conversation box. Sally exchanges news with Anna about her experiences lately. Anna asks her about sally's consumption of drug for her agoraphobia. Sally said that she has reduces the dose of her consumption for drugs. Anna feels jealous toward Sally condition because Anna takes similar medicine as sally however she still cannot reduce the dose of her medicine. There is no improvement in Anna condition. All of the situation can be seen can be seen in the following quotation:

"I'm on a similar drug (among others), and from time to time the headaches nearly rupture my brain. Propranolol can lead to migraine, heart arrhythmia, shortness of breath, depression, hallucinations, decreased libido, insomnia.

"What that medicine needs is more side effects," Ed said to me.

"Spontaneous combustion, the screaming shits. Slow, lingering death." (Finn, 2018: 29)
Based on the above analysis, Agoraphobia makes Anna has to consume a lot of drugs to reduce her disease. One example of the drug Anna needs to consume is Propanolol. The drugs have serious side effect for Anna because it makes Anna in hallucination. She has to consume the drugs even though it will be dangerous for her body. She cannot stop to consume the drugs because her agoraphobia will be more difficult to cure without consuming this drug.

\section{The Influences of Agoraphobia toward Her Surrounding}

Anna see her best friend Katie (she thought as Jane Russell) is having a fight with someone at The Russell's house. Anna has no power to help her neighbor Katie in critical situation. She saw Katie in a bloody chest condition, hanging in the window of her house. She is scary to see the sight. She really wants to help Katie however she has agoraphobia. She is panic, she tries to call the police but she thinks it will be too late to help Katie. She tries to forces herself to go outside of her house but she has no power to go to the open space. All of the evidence above can be seen in the following quotation:

"I set my hand on the knob." I twist. I stand there, the brass cold in my fist.

I can't move. I can feel the outside trying to get in-It' swelling against the door, bulging its muscles, battering the wood; I hear its breath, its nostrils steaming, its teeth grinding. It will trample me; it will tear me; it will devour me. I press my head to the door, exhale. The street is a canyon, deep and broad. It's too exposed. I'll never make it." (Finn, 2018: 149)

Anna tries hard to go outside of her house through her side door in her kitchen in order to help Katie. She takes her umbrella in order to block her view to the open space until she comes to the middle park of her house. She realizes that Russell's house doesn't have a door to the park. She has to walk to the street in order to enter the Russell's house. She is panic and anxiety because of her agoraphobia. She really wants to help her best friend (Katie). However, she has no power to against her Agoraphobia. She tries to force herself against her fear and anxiety but she is in faltered and staggered condition. She is falls down 
unconsciously in the park. The police find her in unconscious condition and take her to the hospital. Anna is so panic in the hospital and she makes the nurses hard to handle her. All of the evidence above can be seen in the following quotation:

"The nurse rounds the bed, zeroes in on the side table. I follow her, my head slowly revolving, and watch as she places a cup in my hands. I sip. Tepid water. "You're under sedation, she tells me, almost apologetic now. "You were fussing a little bit earlier." (Finn, 2018: 159)

Based on the above quotation, the influence of agoraphobia on her surrounding is it makes the nurse is in trouble and hard to handle her. The nurse wants to give her medicine but she is suddenly become panic and feels anxiety because of her Agoraphobia. She is always in a panic condition if she is in the environment she cannot control. She is struggling on her bed and shouts loudly like a crazy woman. This condition makes the nurse quite hard to give her an injection.

\section{CONCLUSION}

From the analysis of the previous chapters it can be concluded that agoraphobia is a type of phobia which makes Anna Fox, the main character of the story afraid to go outside of her house. She is diagnosed by her doctor with agoraphobia problem because when she left her house she suffers panic attack and even unconscious. She is not brave to go outside her house for nearly a year. She has got Agoraphobia due to Post-Traumatic Stress Disorder because of the accident of her family. She drives the car then lose her control and made her family fell into a cliff. The police find them after two days and took them to the hospital but unfortunately her husband (Ed) and her daughter (Olivia) passed away from the accident. After this tragedy, she is afraid to go outside to the open space and this is the beginning of Anna's Agoraphobia.

Agoraphobia also influences herself and her surroundings. Agoraphobia changes her life because she cannot do her activities as usual because she has no power to go the open space. She loses her job and is in a deep depression in her house. Anna also has got bad temperament because of her condition. She feels embarrassed to her surrounding (neighbors). She has to consume a lot of drugs every day even though it has side effects which danger her body. Agoraphobia also influences her surroundings such as Anna cannot help Katie who needs her help when she is in a bloody chest condition. She also makes the nurse in the hospital is in struggle to give her an injection.

\section{REFERENCES}

Abrams, M. H. (1999). A Glossary of Literary Terms. Heinle \& Heinle.

Bernhardt, K. S. (1953). Practical Psychology. McGraw-Hill Book Company.

Braun, J., \& E, D. (1983). Psychology Today. Random House, Inc.

DiYanni, R. (1990). Literature Reading Fiction, Poetry, Drama, and the Essay. The McGraw-Hill, Inc.

Egri, L. (1946). The Art of Dramatic Writing. Simon \& Schuster, Inc.

Finn, A. J. (2018). The Woman In The Window. Harper Luxe.

Frampton, M. (1984). Agoraphobia. Turnstone Press Limited.

Freud, S. (1949). Inhibitions, Symptoms and Anxiety. The Hogarth Press Ltd.

Gill, R. (1995). Mastering English Literature. Palgrave, Ltd.

Griffith, K. (1994). Writing Essays about Literature. Harcourt Brace College.

Haber, A., \& Runyon, R. P. (1983). Psychology of Adjustment. The Dorsey Press.

Kasschau, R. A. (1995). Understanding Psychology. McGraw-Hill.

Kenney, W. (1966). How to Analyze Fiction. Simon and Schuster Division of Gulf \& Western Corporation.

Reaske, R. (1970). The college writer's guide to the study of literature. Random House.

Wellek, R., \& Warren, A. (1949). Theory of Literature. Harcourt Brace \& World, Inc. 